\title{
Strengthen the Impact of CSR Information on Investment Decisions: The Role of Good Corporate Governance in ASEAN Countries
}

\author{
Istianingsih (0000-0002-6144-0371) \\ Economics and Business Faculty, Universitas Bhayangkara Jakarta Raya, Kota Jakarta Selatan, Daerah Khusus Ibukota Jakarta 12550, \\ Indonesia; istianingsih@dsn.ubharajaya.ac.id \\ * Correspondence: istianingsih@dsn.ubharajaya.ac.id
}

\begin{abstract}
This research contributes to the development of theories regarding the relationship between Corporate Social Responsibility (CSR) and investment decisions. Acquisition of stock returns that exceed normal predictions depends on the successful implementation of Good Corporate Governance (GCG). This study aims to examine investors' reactions to information on the disclosure of CSR in several countries that are members of the Association of Southeast Asian Nations (ASEAN). Furthermore, this study also examines the role of implementing GCG in strengthening the impact of CSR disclosure on investor relations as measured by abnormal stock returns. The sampling technique used was purposive sampling. The research was conducted on Manufacturing Companies in countries that are members of ASEAN during 2017-2019. The estimation model used to analyze data is a multiple regression model. The results showed that CSR information was able to increase investors' positive reactions. Meanwhile, GCG practice is proven to strengthen the impact of CSR information on investment decisions. Other variables involved in this study, namely audit quality, company size, debt level, and sales growth, are not proven to influence abnormal stock returns.
\end{abstract}

Keywords: Corporate Social Responsibility; information, Good Corporate Governance; abnormal stock return

\section{Introduction}

There is increasing attention to the relationship between corporate governance and disclosure of CSR in both developed and developing countries [1\}. GCG and CSR implementation can be a positive indicators for the company in every country, including ASEAN members. The ASEAN Economic Community (AEC), launched in 2015, aims to transform ASEAN into a free trade area free of goods, investment, skilled labor, services, and a freer flow of capital. MEA realizes the ultimate goal of economic integration that has been adopted in the ASEAN Vision 2020, which is based on the convergence of the interests of ASEAN member countries to expand and deepen economic integration through existing and new initiatives with clear deadlines. In establishing the AEC, ASEAN must act following the principles of being open, outward-oriented, open, and leading to a market economy that is firm with multilateral regulations and adhering to the system for the implementation and compliance of practical rules-based economic commitments.

It is recorded that there are ten rankings of the prominent foreign investors in ASEAN coming from outside the region, which control about $70-80 \%$ of total foreign investment entering ASEAN. It should be underlined that in 2015 only Indonesia had a larger share of an intra-ASEAN investment than countries outside ASEAN, namely around $56 \%$. Singapore is listed as a country that receives foreign investment flows from outside ASEAN with a significant percentage (92\%). These data indicate that Indonesia and other ASEAN member countries have not shown significant changes as targeted in the AEC in the structure of trade and investment. Orientation with traditional partners (America, Japan, and Europe) is still dominant. This fact shows that the AEC agenda is still not a priority in ASEAN member countries' trade and investment policies. 
In the ASEAN context, the dynamic international situation also presents its challenges. The Brexit phenomenon should be an important note, considering that Britain's exit from the European Union is a challenge for ASEAN to convince every member country of the AEC's equal benefits. Indonesia is one of the ASEAN member countries that has agreed on the ASEAN Economic Community (AEC) agreement. AEC has a pattern of integrating the ASEAN economy by forming a free trade system or free trade between ASEAN member countries. The agreement to form the ASEAN Economic Community began with a summit held in Kuala Lumpur in 1997. In this summit, ASEAN leaders decided to make ASEAN changes to become a prosperous, stable, and highly competitive economic development that applies somewhat and can reduce inequality and poverty. Socioeconomic (ASEAN Vision 2020).

The trading trend in Indonesia is positive, supported by a positive response from the capital market in Indonesia. This response encourages companies to go public. With the increase in companies going public, public accounting firms' need for financial statement audits has also increased. The timeliness of the presentation of financial reports and the auditor's report is a matter of concern in increasing its share price.

The development of the subsequent audit process for publicly traded companies is not easy; this is because the audit process itself takes time, which can cause earnings announcements and financial statement submissions to be delayed, resulting in slow earnings reactions. Audit quality is essential because high audit quality can deliver financial reports and auditor reports promptly, and the resulting information also contains fairness.

With a high audit quality value, there is no doubt about the timeliness of submitting financial reports and the fairness of financial statements. Financial reports are a source of financial information provided by a company to the general public when it has gone public. These financial reports are published for the benefit of the users. The users are investors and creditors and other interested parties such as the government and the public.

Audit quality is important because it can deliver financial reports and auditor reports on time with high audit quality; the resulting information also contains reasonableness. With high audit quality, there is no doubt about the timeliness of submitting financial reports and the fairness of financial statements [2]. Financial reports are sources of financial information provided by a company to the general public and investors when the company has gone public.

One of the factors that also affect investor value is implementing GCG in the company [3] Indonesia; it started to get attention after the crisis in 1998. At that time, many companies collapsed due to poor corporate risk management. Besides, the lack of transparency on the company's condition is also seen as the cause of the crisis. GCGis the main topic of discussion in the process of economic recovery. The government and the Indonesian economic community's attention has also increased on the importance of implementing GCG as a fundamental factor for long-term economic resilience and stability [2-4].

"The development of ethical issues in company management encourages companies to be more serious in implementing CSR. The CSR concept guides companies to seek profit (profit), a short-term goal, and safeguard long-term interests by applying three basic principles known as the triple bottom line: profit, people, and the planet. "These three principles guide companies to participate in the welfare of social life (people) and ensure the sustainability of the environment (planet) to protect its long-term interests" [5].

For investors, there are various purposes to buy shares. Some aim to obtain profit from stock price fluctuations by buying shares when the price drops and selling shares when the stock price rises. The rest are aimed at obtaining dividends paid by the company every time - the year [6]. Investors also want to get profits through investments 
made later, namely in the form of Return on investment in the form of dividend income and (capital gain), namely the difference between the shares minus the shares [6-7].

To get this Return, investors need the information to choose the right time to determine whether to buy, sell, or hold a security. This information is beneficial for investors in making investment decisions [8]. This condition will be fulfilled if the capital market is in an efficient condition.

Investor reactions are responses from investors themselves to the company's information and can be positive or negative. According to [6-7], they states that if a capital market reaction to accounting information is observed using an event window for several days, covering an earnings announcement, it can be said that accounting information is the cause of market reaction (investors). If the announcement contains information (information content), it is expected that investors will react at the time of the announcement and the investor receives the information [9]. Investor reactions can be seen from changes in the securities' stock price in question and changes in share trading volume [10].

From the investor's point of view, dividend policy is an important indicator to determine the extent to which investors' investment in a company can provide returns by the level indicated by investors

in the event of a surprise return or abnormal Return at the time of the earnings announcement [11]. It can be said that an announcement that contains information will give investors an abnormal return. Conversely, those that do not contain information do not give investors an abnormal return. Testing the information content of earnings is only limited to testing investors' reaction (the market), but does not test how fast the market reacts $[6.7,12]$. The reaction of investors (market) is indicated by the significant changes in stock prices (stock returns) of certain companies at the time of earnings announcements, namely that there is a large enough difference between the Return that occurs and the Expected Return [6.7.12.13]

The implementation of GCG and CSR is important because it has a profit objective and ensures its sustainability [14]. Good company management will increase shareholders' investment value in the long term and ultimately increase stakeholder trust, including investors. CSR also has a relationship with market valuation where if the company has good environmental and social performance, it will be responded positively by investors through an increase in stock prices. Then, by looking at the different economic Growth in the ASEAN region, the question arises which factors affect the region's economic growth. This study's development is to add the audit quality factor from previous research on the effect of GCG and CSR Disclosure on Abnormal Return on manufacturing companies in ASEAN countries.

Researchers chose companies in ASEAN countries with a large frequency and number of transactions, bright company prospects, stable financial conditions. The mass media and the public more highlighted them because their operational activities could intersect with broad interests. It is also hoped that this research can contribute thoughts about the importance of CSR disclosure and the application of GCG in ASEAN countries. For investors and potential investors, it can be used as information and input in making decisions when investing in the target company [15-16]. This study aims to determine how audit quality and GCG and CSR as a moderator can influence investors' reactions in 36 companies in ASEAN countries and become participants in the ASEAN CG Scorecard Country Report and Assessments for the 2017 period.

2. Literature Review

2.1. Agency Theory

Investor and management relations can be seen from agency theory [17]. Meanwhile, the public accounting firm plays a role in examining the financial statements presented by Management to be used by investors in predicting the company's future earnings, whether the company has good prospects or vice versa, so that investors can make decisions about their investment. An investor can carry out a passive investment strate- 
gy, namely buying stocks and holding them for an extended period regardless of market fluctuations if the company has good prospects. The agency theory developed by [17] views that company management as an agent, will act with full awareness for their interests, not as a party who is wise and prudent and fair to shareholders.

Agency theory bases the contractual relationship between the company's members, the principal, and the agent as the main actors [17-18]. Principal mandates the agent to act on behalf of them, while an agent is mandated to run the company. The agent is obliged to account for what has been mandated by the principal [17-18].

\subsection{Signaling Theory}

Information is considered useful if it can change investors' confidence. Investors need information about the company to decide whether to invest in the company; this is in line with the signaling theory [6]. Information asymmetry will occur if Management does not fully convey all the information it knows about everything that can affect the company's value to the capital market [6.17]. Lack of outside information about the company causes them to protect themselves by giving the company low prices. Firms can increase firm value by reducing information asymmetry. One way to reducing information asymmetry is by giving signals to outsiders [10,12,19]. Management can deliver information to the market. Generally, the market will respond to this information as a signal that can be in the form of good news or bad news regarding certain events that can affect the company's reflected value from changes in the price and trading volume of shares $[6,10.2,17,19]$.

\subsection{Previous Research}

The great trust of users of audited financial statements and other public accountants' services ultimately requires public accountants to pay attention to the quality of the audits they produce [20]. The large public accounting firm can carry out auditing more efficiently and effectively and has greater flexibility in audit scheduling [20,21].

In simple terms, corporate governance can be defined as a system regulating and controlling the company to create added value (value-added) for all stakeholders [22]. The main objective of realizing long-term shareholder value while taking into account other parties' interests [23].

Research by [24] defines corporate governance as a set of provisions that enable the stockholders to exercise voting power to compel those in the firm's operating control to respect their interests. GCG is a system that regulates and controls the company[10,25]. GCG aims to create added value for all interested parties [26].

On the other hand, understanding CSR4 is described as something that is enriched by natural science [27]. According to [28] CSR is defined as the follow-up of companies in implementing effective GCG to realize the sustainability created through transparent and accountable business implementation. Understanding CSR1 focuses on CSR as a test tool for companies, whether they have fulfilled their obligations to work for social good [29]. Meanwhile, [30] defines CSR as the company's responsibility to run a business following shareholders' desires, which in general is to make as much money as possible while still complying with the regulations in society, both those that apply legally as well as ethically.

A company in an industry with a high growth rate must provide sufficiently high capital to finance the company. Companies with high sales growth tend to have a high level of risk, too [30-33]. The research of [34] analyzed the differences in CSR disclosure and showed differences in corporate governance composition, which is reflected in institutional investors' role in the two countries. Research examining the relationship between voluntary and committee disclosure was conducted by [35]. The results showed a positive relationship between an audit committee's existence and voluntary disclosures made by the company. 
[30] found that CSR corporate governance and auditing are interactively related. To fulfill CSR and ensure sustainable Growth and development, companies must build and implement corporate governance. [10] found that the majority of managers understand corporate governance as an important pillar for sustainable CSR. Companies without an efficient long-term perspective on leadership, effective internal control mechanisms, and strong reciprocal responsibility with internal stakeholders cannot carry out CSR's true meaning. On the other hand, corporate governance will not be effective without a sustainable CSR drive because it responds to stakeholders' needs to generate profits and create company value for owners and other stakeholders.

\subsection{Research Framework}

Based on the previous description and literature review, the variables involved in this study can be formulated into the following framework:

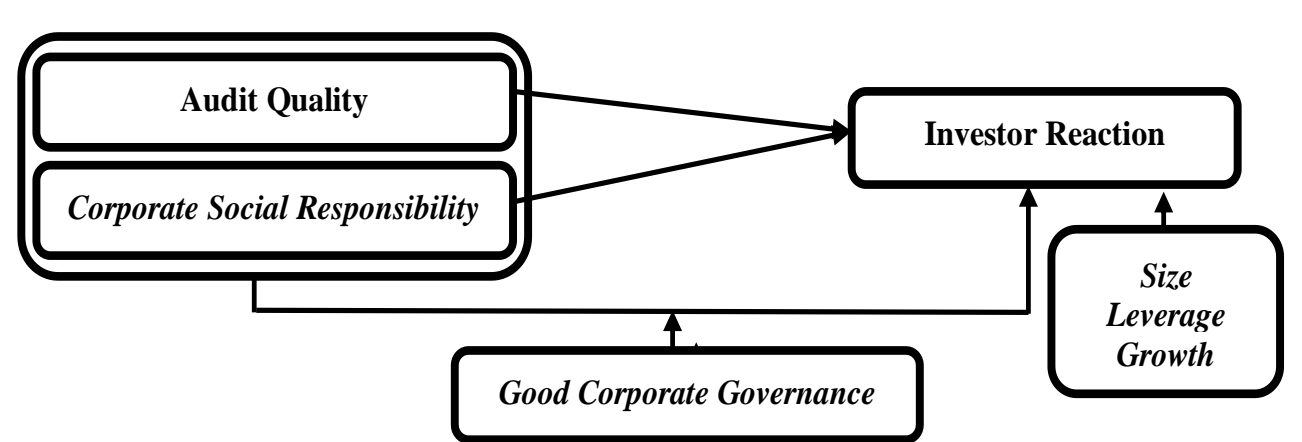

Figure 1. Research Framework

\subsection{Research Hypothesis}

1) The effect of audit quality on investors' reactions.

Audit quality is important because high audit quality can deliver financial reports and auditor reports on time, and the resulting information also contains fairness [2.20]. With high audio quality, there is no doubt about the timeliness of submitting financial reports and the fairness of financial statements. Financial reports are a source of financial information provided by a company to the general public when it has gone public. These financial reports are published to benefit investors and creditors, and other interested parties such as the government and the public. Based on the explanation above, the proposed hypothesis formulation is as follows:

H1: Audit quality affects investors' reactions

2) The influence of Corporate Social Responsibility on investor reactions.

Information in the company's financial statements has a critical role in the capital market, both for individual investors and the market as a whole [3,8-9]. For investors, information plays an important role in making investment decisions, while the market uses it to reach new equilibrium prices. Investors consider profit as the only consideration, but investors are starting to see the disclosure of corporate social responsibility to the environment. Companies that voluntarily disclose positive environmental information result in the risk of reduced prosperity that the company may face in the future to influence investors in making decisions. Information can be useful if it can cause a change in the recipient's confidence and trigger certain actions reflected in price changes. If market players (investors) consider this good information news, there will be investor reactions reflected by changes in stock prices.

Changes in stock prices can be described in terms of capital market efficiency. The form of capital market in ASEAN Countries are close to semi-strong efficient market form. Semistrong form in an informed manner, which is reflected in the speed with which investors react to new information entry [8]. A semi-strong efficient market (sem- 
istrong form) can be tested by looking at the abnormal returns that occur through stock price changes [8,11]. Abnormal return is the difference between actual return and expected return [11]. Investors will react positively to good corporate value. Based on the explanation above, the proposed hypothesis formulation is as follows:

H2: CSR affects investors' reactions.

3) The effect of GCG moderates the relationship between audit quality and investor reactions.

With good audit quality, investors will respond more quickly to the information presented by a company. Companies that KAP Big4 audits will have better audio quality than those that are not Big4; besides, companies that Big4 audits will be more transparent in providing opinions and information $[2,20]$. Transparent audits of financial reports and annual reports it is supported by GCG. Following the values tested in the assessments, the ASEAN CG scorecard can make the company better and disclose it in the company's financial reports and annual reports and the company's sustainability report. The implementation of GCG will affect the quality of the company's audit. So based on this description, the formulation of the hypothesis proposed is as follows:

H3: Good Corporate Governance moderates the relationship between audit quality and investor reactions.

4) The influence of GCG moderates corporate social responsibility's relationship to investors' reactions.

As in the previous discussion, CSR implementation in companies can be used to attract investors; it's just that CSR is carried out if the company has implemented good corporate governance [3,9]. Because the company responds to the needs of stakeholders to generate profits and create company value for owners and other stakeholders, based on this description, the proposed hypothesis formulation is:

H4: GCG moderates the relationship of CSR to investor reactions.

3. Research Design

3.1.Type of Research

This research is causal, namely research that aims to test the hypothesis about the influence of one or more variables on other variables. Researchers use this research design to provide empirical evidence about the Effect of Audit Quality and CSR on Investor Reactions with GCG as a Moderating Variable.

3.2. Variables Operationalization

3.2.1. Corporate Social Responsibility

Disclosure of Corporate Social Responsibility is defined as data disclosed by companies relating to social activities carried out by the company. This variable is measured through the CSR Index (CSRI). CSRI assesses social responsibility according to the criteria according to GRI, namely: Economic, Environmental Performance, Human Rights, Labor Practices \& Decent Work, Society, and Product Responsibility. Disclosure of CSR information in annual reports and sustainability reports of business entities is calculated using the CSR disclosure index with the GRI version 4.0 standard, totaling 161 items, then adjusted back to each company. The CSRI calculation is done by giving a score of 1 if one item is disclosed and 0 if it is not disclosed. After scoring all items, the scores are then added to obtain the overall score for each company. The CSRI calculation formula is:

$$
\operatorname{CSRIj}=\frac{\sum X_{i j}}{n_{j}}
$$

CSR: Company Corporate Social Responsibility Index j

$\sum$ Xij: Number of items that the company disclosed $j$

NJ: Number of items for companies based on GRI 4.0 Index (161 items)

\subsection{Good Corporate Governance}

In this study, good corporate governance was measured using the ASEAN CG Scorecard Country Reports and Assessments 2017 using the level 1 assessment category (179 items). This method use because not all companies listed in the ASEAN CG Score- 
card Country Reports and Assessments have applied a two-level assessment. The calculation of the assessment at level 1 is as follows:

The assessment at level 1 contains five main aspects that refer to OECD principles, and each aspect has 179 items that are used as guidelines. The five aspects are:

Table 1. Level 1 Structure and Composition

\begin{tabular}{|l|c|c|c|}
\hline \multicolumn{1}{|c|}{ Level 1 } & $\begin{array}{c}\text { Number of } \\
\text { Questions }\end{array}$ & $\begin{array}{c}\text { Weight } \\
\text { (\% of total } \\
\text { level 1 Score) }\end{array}$ & $\begin{array}{c}\text { Max. } \\
\text { Attainable } \\
\text { Score }\end{array}$ \\
\hline Part A: Rights of Shareholders & 25 & 10 & 10 Points \\
\hline Part B: Equitable Treatment of Shareholders & 17 & 15 & 15 Points \\
\hline Part C: Role of Stakeholders & 21 & 10 & 10 Points \\
\hline Part D: Disclosure and Transparency & 41 & 25 & 25 Points \\
\hline Part E: Responsibilities of the Board & 75 & 40 & 40 Points \\
\hline
\end{tabular}

(Source: ASEAN CG Scorecard Assessment 2017)

To compute the score for level one si as follow Bulleted lists look like this:

$$
\text { Score }=\frac{\text { Number of items Scored by PLC }}{\text { Total no. of Questions }} \times \text { Max } \text {. attainable score ( ) }
$$

These five aspects can be explained as follows:

1. Protection of the rights of shareholders (The rights of shareholders).

2. The same treatment of shareholders (The equitable treatment of shareholders).

3. The role of stakeholders in corporate governance.

4. Disclosure and transparency.

5. Responsibilities of the Board of Commissioners and Directors

\subsubsection{Abnormal Return}

The measurement of abnormal Returns uses market-adjusted models. The market model assumes that the best measurement is the market index return [11]. In this model no need to use the estimation period to form an estimation model because the estimated security return is the same as the return index market in the same period. In this case, the market return index uses the Return from the composite stock price index. Here is the formula for calculating the abnormal Return:

ARit: Rit - Rmt

Information :

$$
\begin{gathered}
\mathrm{R}_{\mathrm{it}}=\frac{\mathrm{P}_{\mathrm{it}}-\mathrm{P}_{\mathrm{it}-1}}{\mathrm{P}_{\mathrm{it}-1}} \\
\mathrm{R}_{\mathrm{mt}}=\frac{\mathrm{IHSG}_{\mathrm{t}}-\mathrm{IHSG}_{\mathrm{t}-1}}{\mathrm{IHSG}_{\mathrm{t}-1}}
\end{gathered}
$$

ARit $=$ Abnormal Return for a company $i$ on day $t$

Rit $=$ Daily company return on day $t$

$R m t=$ Return of the market index on day $t$

Pit $=$ share price of a company $i$ at time $t$

Pit-1 = share price of a company $i$ at time $t-1$

IHSG $\mathrm{t}=$ composite stock price index at time $t$

IHSGt- $1=$ composite stock price index at time $\mathrm{t}-1$ 


\subsection{Quality Audit}

In this study, auditors' quality is proxied by the audit company's size that audits annual financial reports, referring to whether the relevant KAP is affiliated with the big four or not.

\subsubsection{Control Variables}

This research use size, leverage, and growth to control investor reaction. The use of the three variables are base on [32] suggestion. Size is formulated as follows [32]:

SIZE $=\log$ (book value of total assets)

Leverage views by the level of Debt to Equity Ratio follow [32] formula:

$$
D E R=\frac{\text { Total Debt }}{\text { Total Equity }}
$$

The company's sales growth is a proxy for measures company growth in this study. The formula used to measure the Growth variable is

$$
\text { Growth }=\frac{\text { Sales }_{t}-\text { Sales }_{t-1}}{\text { Sales }_{t-1}}
$$

\subsection{Population and Sample}

This study's population comprises six ASEAN countries (Indonesia, Singapore, Malaysia, Thailand, Philippines, and Vietnam) that are members of the ASEAN CG Scorecard Country Reports and Assessments. Sampling was done by purposive sampling, which is part of the non-probability sampling method. Sampling-based on the following criteria:

1. The company was included in the ASEAN CG Scorecard Country Reports and Assessments in 2017

2. Manufacturing companies that are members of the ASEAN CG Scorecard Country Reports and Assessments in 2017

3. The company uses the Global Reporting Initiative (GRI) version 4.0 (G4) standard in disclosing its Corporate Social Responsibility

4. The company has complete data following the needs of the research sample.

5. The company publishes financial reports in English.

Data collection technique

The data collection method in this research is carried out in the following ways:

1. Documentation, namely the collection of data available on the research object.

2. Literature study, namely from the literature related to the problems in writing this research.

Data analysis method

This research use Moderate Regression Analysis (MRA) Testing Model

$$
\begin{gathered}
A R_{I t}=\alpha+\beta_{1} K A_{t}+\beta_{2} C S R_{t}+\beta_{3} G C G_{t}+\beta_{4} K A_{t}^{*} G C G_{t}+\beta_{5} C S R_{t}^{*} G C G_{t}+\beta_{6} S I Z E_{t}+ \\
\quad \beta=L E V_{t}+\beta_{8} G R O W T H_{t}+\mathrm{e} \\
\text { Information: }
\end{gathered}
$$

ARIt: Investor reaction in year $\mathrm{t}$

$\alpha$ : Constant

$\beta_{1} \beta_{2} \beta_{3} \beta_{4} \beta_{5} \beta_{6} \beta_{7} \beta_{8}$ : Regression Coefficient

KAt: Audit quality in year $t$

GGCT: ASEAN CG Scorecard in year $\mathrm{t}$

CSR: CSR Index in year $t$

KAt * GCGt: The interaction between audit quality and GCG in year $t$

CSR * GCGt: The interaction between CSR and GCG in year $t$

SIZEt: Company size in year $t$

LEVt: Leverage in year $t$ 
growth: Quality Audit in year t

e: Error

4. Research Result and Discussion

4.1. Sample

Based on data obtained from the official website of the ASEAN Corporate Governance Scorecard or http://www.theacmf.org, it is known that the companies that met the criteria in the purposive sampling during the research year (2017-2019) were 36 companies. They are consist of Indonesia, Malaysia, Philippines, Thailand, and Vietnam.

Table 2. Descriptive Statistics

\begin{tabular}{|l|r|r|r|r|r|}
\hline & $\mathrm{N}$ & Minimum & Maximum & Mean & Std. Deviation \\
\hline KA & 108 & 0 & 1 & .92 & .278 \\
GCG & 108 & .37 & .79 & .6229 & .08656 \\
AR & 108 & -.05 & .11 & .0037 & .02588 \\
CSR & 108 & .04 & .91 & .3219 & .19415 \\
KA_GCG & 108 & .00 & .79 & .5660 & .19112 \\
CSR_GCG & 108 & .03 & .53 & .1991 & .12470 \\
SIZE & 108 & 19.66 & 33.20 & 26.7959 & 3.98603 \\
DER & 108 & .03 & 3.94 & 1.0939 & .89327 \\
G & 108 & -.94 & .92 & .0491 & .19434 \\
Valid N (listwise) & 108 & & & & \\
\hline
\end{tabular}

The GCG variable measured using the self-assessment of the ASEAN GC Scorecard Level 1, totaling 179 assessment items, had an average value of $63 \%$. The higher the level of GCG, the higher the quality of published financial reports. The better the implementation of GCG in the company can also reduce the abuse of authority and delegation in the company, thereby ensuring investor confidence and return.

The CSR variable has the average number of items disclosed by the sample company is approximately 50 out of 161 items that must be disclosed. This number shows that, on average, the sample companies that participated in the ASEAN CG Scorecard Assessment 2017-2019 have not disclosed much about CSR carried out by companies. Hence, governments in each country need to set rules to report CSR in Sustainability Reporting specifically. T

he GCG value from the results of this study shows that Thailand has the greatest value. This result proves that the implementation of GCG is good and is a signal for investors to invest. Petronas, Malaysia, achieve the best CSR value. The company has made a long-term commitment to the CSR program to help the government improve its young generation's capabilities and reduce emission levels that reduce environmental pollution. This result is a good signal for investors, especially investors who consider environmental values, eco investing, and green bond investors.

Table 3. Regression Coefficienta

\begin{tabular}{|c|c|c|c|c|c|c|}
\hline \multirow{2}{*}{\multicolumn{2}{|c|}{ Model }} & \multicolumn{2}{|c|}{$\begin{array}{c}\text { Unstandardized } \\
\text { Coefficients }\end{array}$} & \multirow{2}{*}{$\begin{array}{l}\text { Standardized } \\
\text { Coefficients } \\
\text { Beta }\end{array}$} & \multirow[b]{2}{*}{$\mathrm{t}$} & \multirow[b]{2}{*}{ Sig. } \\
\hline & & B & Std. Error & & & \\
\hline \multirow[t]{3}{*}{1} & (Constant) & -.014 & .067 & & -.207 & .837 \\
\hline & KA & -.352 & .150 & -3.774 & -2.343 & .021 \\
\hline & GCG & .269 & .126 & 1.589 & 2.139 & .035 \\
\hline
\end{tabular}




\begin{tabular}{l|r|r|r|r|r|}
\hline CSR & .020 & .009 & .604 & 2.167 & .033 \\
KA_GCG & .491 & .221 & 3.629 & 2.222 & .029 \\
CSR_GCG & -.115 & .058 & -.550 & -1.984 & .050 \\
SIZE & -.001 & .001 & -.121 & -1.146 & .254 \\
DER & .002 & .003 & .075 & .783 & .435 \\
G & .023 & .013 & .175 & 1.746 & .084 \\
\hline
\end{tabular}

A

. Dependent Variable: AR

1) The effect of audit quality on investors' reactions

The results of this study indicate that audit quality affects investors' reactions (abnormal Return). Audit quality is important because it can ensure that its financial reports and sustainability reports are presented in a timely, reliable, and accurate manner. It can help investors make the right decisions on their investment plans and the returns they will get based on real financial data from the company. The use of competent auditor office services, especially "The Big Four," can increase its credibility and make a good judgment for investors.

Audit quality is not something that can be enjoyed immediately. Perceptions of audit quality are further related to the name and credibility of the auditors. In this case, the good name of the company is the most important picture. Both theoretically and empirically, auditor quality is often measured using the size of the public accounting firm.

$[2,20]$ states that "the auditor's report contains three groups of interests, namely: (1) the manager of the company being audited; (2) Company shareholders; (3) third parties or external parties such as potential investors, creditors, and suppliers. Each of these interests is a source of interference that will pressure the auditor to produce reports that may not follow professional standards, further in this case, and it can interfere with audit quality."

2) The influence of Corporate Social Responsibility on investor reactions

The test results on the CSR variable show a significance value of $0.02(<0.05)$. A significant value less than 0.05 means that CSR affects investors' reactions, which proxied by abnormal returns. This result follows the initial assumption that there is a positive correlation between CSR information disclosure in the sustainability report on investor reactions. The higher the CSR disclosure indicates, the better its investor signal; it can expand the company's operations and expand the company. Management is considered capable of managing its economic resources properly to fulfill the interests of its stakeholders. Thus, its stakeholders' interests can be fulfilled, and the company's reputation will increase and public trust in information on earnings reported by the company.

This study's results support the research conducted by [9], which found that companies' CSR disclosures can influence investors' reactions to earnings announcements in their annual reports. [32] revealed that earnings' informativeness would be greater when uncertainty about the company's prospects in the future $[17,18]$. It is hoped that if the company discloses CSR information in its annual report, it will reduce this uncertainty. This condition indicates that investors appreciate the company's CSR information as a basis for making investment decisions. 
3) The effect of Good Corporate Governance moderates the relationship between audit quality and investor reactions

This study's regression results indicate that the GCG variable moderates the relationship between audit quality and abnormal returns (investor reactions). This variable research results have a significant value, meaning that GCG and audit quality can influence investors' reactions. This result is in line with [36] previous research on the impact of good corporate governance on financial performance, stock trading volume, and abnormal returns, finding a significant positive effect of GCG on abnormal returns. This result means that the better corporate governance, the higher the abnormal return value [37].

4) The effect of Good Corporate Governance moderates the relationship between audit quality and investor reactions

This study's regression results indicate that the GCG variable moderates the relationship between audit quality and abnormal returns (investor reactions). This variable research results have a significant value, meaning that GCG and audit quality can influence investors' reactions. This result is in line with [2] previous research on the impact of good corporate governance on financial performance, stock trading volume, and abnormal returns, finding a significant positive effect of GCG on abnormal returns [9.38]. This sign means that the better the implementation of corporate governance, the higher the abnormal return value. The significant results indicate that research on companies in ASEAN countries has mostly implemented good corporate governance and has followed the ASEAN CG Scorecard assessment. Thus, the company already has good governance, which can increase investor confidence [39]. Furthermore, investors will respond more quickly to the company's information [20].

Companies audited by KAP "The Big Four" will have better quality audit results compared to companies audited by not "The Big 4"; besides, companies audited by "The Big Four" will be more transparent in providing opinions and information.

5) The effect of GCG moderates the relationship between CSR and investor reactions

This variable's research results indicate a significance value of 0.05 that GCG can moderate the relationship between CSR and investor reactions (abnormal Return). The CSR value, which initially had a positive relationship with investors' reactions, became negative after being moderated by the GCG variable [40]. This value indicates that the higher the value of CSR moderated by GCG, the lower the investor's reaction (abnormal Return) will be. In this case, GCG can moderate the relationship between CSR and Investor Reaction.

Investors are influenced by the implementation of the value of Corporate Governance by the Management. Companies that have implemented good corporate governance will pay attention to social values as a responsibility for the environment. One of the manifestations is the implementation of CSR in companies. This CSR is also one of the considerations for investors in investing. [41] shows that the implementation of corporate governance mechanism, which is reflected in the four principles, namely transparency, fairness, accountability, and responsibility, partially or simultaneously has a significant effect on stock price changes, which can be seen from the abnormal Return [36,40]. Following the concept of stakeholder theory, with a GCG mechanism in a company, the level of stakeholder trust in the company will increase [43]. With this increase in trust, it can provide a positive signal effect in the form of good news for investors to buy shares to increase stock prices.

6. The effect of control variables

The test results on the Size variable shows that investors consider the information on company size not informative enough to measure company performance. Debt to Equity Ratio (DER) does not affect abnormal returns. The growth variable's test results show that Growth affects Investor Reactions. The results of this study are following [32]. This result is not in line with previous research by [9]. 


\section{Conclusions}

The research conclusion that Audit quality has a negative effect on Abnormal Returns. CSR has a positive effect on Abnormal Return. GCG is proven to moderate audit quality on abnormal returns. GCG is proven to moderate CSR towards Abnormal Return.

Investors and potential investors can make the value of GCG and CSR disclosure a consideration for investing in ASEAN countries. In this case, companies should implement GCG and CSR to open up opportunities for foreign investors to invest, take part in assessments, and find out about the implementation of GCG and CSR in their companies. GC Scorecard Assessment with 179 items at level 1 can be used to assess the company. It is hoped that with good GCG implementation, investors can see the company's business continuity.

For companies implementing CSR, they should do it seriously and seriously. The company assigns CSR staff, forms a separate division, and dedicates CSR funds itself not from company profits but also its annual budget. A good financial report value can automatically attract investors' reactions from within the country and other ASEAN countries to invest and expand.

Regulators in each ASEAN country should be able to reexamine what indicators need to be considered as a reference basis for companies with good corporate governance in practice because differences in regional layout and some local values may also affect. Good GCG implementation can reduce abuse of authority and fraud in the company. CSR disclosure and implementation of GCG in companies in ASEAN countries can influence investment decisions. The policymakers should review the standard values of GCG and CSR, standardize disclosure for valid items, and be disclosed.

This research has some limitations; 1 ) The score of the CSR disclosure index and the assessment index for implementing annual GCG, which the researcher assesses. This assessment is based on the interpretation of the information on the annual report of the sample companies, thus allowing differences in the assessment between companies due to the researcher's subjective interpretation (data limitations). 2) Access to financial reports and sustainability reports that do not use English can make data collection difficult. Several companies have not published their Financial Reports in the 2019 period.

Suggestion for further researchers; 1 ) This study took a sample of the TOP 50 group of manufacturing companies in the ASEAN Corporate Governance Scorecard Country Report and Assessments within three years (2017-2019). To find a more profound influence between ASEAN countries and broader coverage in the future, further researchers can use industrial groups or other measurement indexes as research samples. They can also use a longer observation period to provide a greater possibility to obtain actual conditions, and results obtained may reflect the company's historical management policies. Enrich data by collecting primary data, conducting interviews, surveys, etcetera., so that research is more comprehensive data. For research on Investor Reaction, which is proxied by subsequent abnormal returns, it is suggested to add other control variables that are considered influential in enriching the research. Besides, further researchers can also add the period of the study. 2) This research analysis results are expected for investors or market players to consider companies that have implemented good corporate governance and corporate social responsibility to the environment and society in their investment considerations in the capital market. With the company's large number of CSR disclosures, investors can find out how the prospects for future profits and the company's sustainability are. They can know the guarantee of their investment and can be used to assess the company's performance or financial condition and obtain optimal profits. 3) Management should start to consider the application of GCG and CSR to society. Management was making reporting from this implementation as one of the components of annual reporting because these two indicators are considered for investors in investing their funds. Management's disclosure of social responsibility and corporate governance activities is expected to be more open and known by investors. 


\section{References}

1. Abdulnaser Ibrahim Nour. Abdel-Aziz Ahmad Sharabati. Khitam Mahmoud Hammad. 2020. Corporate Governance and Corporate Social Responsibility Disclosure. December 2019. International Journal of Sustainable Entrepreneurship and Corporate Social Responsibility 5(1):20-41. DOI: 10.4018/IJSECSR.2020010102

2. Jaya, S. M. A., Bambang, P., \& Endang, M. (2017). The Effect of Corporate Governance Mechanism, Ownership Structure, and External Auditor Toward Corporate Social Responsibility Disclosure with Earning Management as Moderating Variable. RJOAS, 8(68), 41-52. doi:10.18551/rjoas.2017-08.07

3. Istianingsih. The Effect of Corporate Social Responsibility and Good Corporate Governance on Pharmaceutical Company Tax Avoidation in Indonesia. Syst. Rev. Pharm. 2020, 11 (12). 977-983

4. Punit Arora and Ravi Dharwadkar. 2011. Corporate Governance and Corporate Social Responsibility (CSR): The Moderating Roles of Attainment Discrepancy and Organization Slack. March 2011. Corporate Governance An International Review 19(2):136 - 152. DOI: 10.1111/j.1467-8683.2010.00843.x

5. Velasques, M. 2012. Business Ethics: Concepts and Cases, 7th Edition. New Jersey: Pearson

6. Scott, W. R. (2015). Financial Accounting Theory (7th ed). Toronto: Pearson Canada Inc.

7. Lev, B.; Zarowin, P. The Boundaries of Financial Reporting and How to Extend Them. J. Account. Res. 1999, 37, 353-385. Vol. 37, No. 2 (Autumn, 1999), pp. 353-385 (33 pages)

8. Istianingsih, Terri Trireksani; Daniel T. H. Manurung. 2020. The Impact of Corporate Social Responsibility. Disclosure on the Future Earnings Response Coefficient (ASEAN Banking Analysis). Sustainability 2020, 12, 9671; doi:10.3390/su12229671

9. Istianingsih. Impact of Corporate Governance in Supply Chain Management. International Journal of Supply Chain Management 9 (Vol. 9, No. 3, June 2020

10. Istianingsih, AH Mukti. Does Corporate Governance as a Moderating Variable Influence the Relationships Between Asmmetry Information and Earning Management?. Internasional Business Management 11 (4), 859-864

11. Jogiyanto, 2014.Teori Portofolio dan Analisis Investasi. Edisi ke 10. Yogyakarta :BPFE

12. Damiti, F., Sutrisno, T., \& Andayani, W. (2018). The Role of Corporate Governance in the Moderation of the Influence of Disclosure of Social Responsibility of the Company on Investor Reactions. International Journal of Business, Economics, and Law, 15(5), 161-170.

13. Deegan, C. (2002). Introduction: The legitimising effect of social and environmental disclosures - A theoretical foundation. Accounting, Auditing \& Accountability Journal, 15(3), 282-311. doi:10.1108/09513570210435852

14. Dwi Nita Aryani, Bernad Engelberd Niron. 2017. Good Corporate Governance on Corporate Social Responsibility with Profitability, Size and Leverage as Moderating Variables (case study at Regional Development Banks in Indonesia). Proceedings of the 1st International Conference on Intellectuals' Global Responsibility (ICIGR 2017). DOI https://doi.org/10.2991/icigr-17.2018.67

15. Haniffa, R. M., \& Cooke, T. E. (2005). The impact of culture and governance on corporate social reporting. Journal of Accounting and Public Policy, 24(5), 391-430.

16. Monika, L. T., \& Khafid, M. (2017). The Effect of Financial Performance on Corporate Value with CSR Disclosure and GCG Mechanism as Moderating Variables. Accounting Analysis Journal, 5(3), 197-204.

17. Jensen, M. C., \& Meckling, W. H. (1976). Theory of the Firm: Managerial Behavior, Agency Costs, and Ownership Structure. Journal of Financial Economics, 3 (4), 305-360.

18. Jensen, M. C. (1993). The modern industrial revolution, exit, and the failure of internal control systems. The Journal of Finance, 48(3), 831-880. doi:10.1111/j.1540-6261.1993.tb04022.x

19. Yu, H.-C., Kuo, L., \& Kao, M.-F. (2017). The relationship between CSR disclosure and competitive advantage. Sustainability Accounting, Management and Policy Journal, 8(5), 547-570.

20. Purba, D. M. (2016). The Influence of Good Corporate Governance and Audit Quality against the Disclosure of Corporate Social Responsibility. The Accounting Journal of Binaniaga, 1(02), 1-16.

21. Chariri, A., Januarti, I., \& Yuyetta, E. N. A. (2017). Firm Characteristics, Audit Committee, and Environmental Performance: Insights from Indonesian Companies. International Journal of Energy Economics and Policy, 7(6), 19-26.

22. Abdulnaser Ibrahim Nour. Abdel-Aziz Ahmad Sharabati. Khitam Mahmoud Hammad. 2020. Corporate Governance and Corporate Social Responsibility Disclosure. December 2019. International Journal of Sustainable Entrepreneurship and Corporate Social Responsibility 5(1):20-41. DOI: 10.4018/IJSECSR.2020010102

23. Abriyani, D. R., \& Wiryono, S. K. (2012). The Effect of Good Corporate Governance and Financial Performance on the Corporate Social Responsibility Disclosure of Telecommunication Company in Indonesia. Indonesian Journal of Business Administration, 1(5), 296-300.

24. Adnan, S. M., Hay, D., \& van Staden, C. J. (2018). The influence of culture and corporate governance on corporate social responsibility disclosure: A cross country analysis. Journal of Cleaner Production, 198, 820-832. doi:10.1016/j.jclepro.2018.07.057

25. Al-Arusi, A. S., Selamat, M. H., \& Hanefah, M. M. (2009). Determinants of financial and environmental disclosures through the internet by Malaysian companies. Asian Review of Accounting, 17(1), 59-76. doi:10.1108/13217340910956513

26. Ali, M. A. M., \& Atan, R. H. (2013). The relationship between corporate governance and corporate social responsibility disclosure: a case of high Malaysian sustainability companies and global sustainability companies. South East Asia Journal of Contemporary Business, Economics and law, 3(1), 39-48. 
27. Frederick, W.C. (1986). Toward CSR3: Why ethical analysis is indispensable and unavoidable in corporate affairs. California Management Review. Vol 28, Issue 2, pp 126-141

28. Frederick, W.C. (1994). " From CSR1 to CSR2: The Maturing of Business and Society Thought.” Business and Society, 33, 2: 150-164 “Coda: 1994."1994. Business and Society, 33, 2: 165-166

29. Frederick, W.C. (1998). " Moving to CSR4: What to Pack for the Trip."1998. Business and Society, 37, 1: 40-59

30. Arani, M.H.Z. (2016). The Effect of Corporate Governance Mechanisms on Social Responsibility Disclosure. Mediterranean Journal of Social Sciences, 7(4S2), 139-146.

31. Bangun, N., Andhika, C., \& Wijaya, H. (2016). Pengaruh tipe industri, mekanisme corporate governance, dan ukuran perusahaan terhadap corporate social responsibility disclosure. Jurnal Bisnis dan Akuntansi, 18(2), 123-130.

32. Yosefa Sayekti, Ludovicus Sensi Wondabio. Pengaruh CSR disclosure terhadap earning response coefficient. Pengaruh CSR disclosure terhadap earning response coefficient. Simposium Nasional Akuntansi X, 2007. Padang, Indonesia

33. Rasyid, A., \& Ardana, I. C. (2016). The Relationship between Corporate Governance, Corporate Size, Corporate Industry to Corporate Social Responsibility Disclosure Size and Stock Price. Proceedings of the International Conference on Education for Economics, Business, and Finance (ICEEBF) (pp. 415-429). Academic Press.

34. Ghazali, N. A. (2010). Ownership structure, corporate governance and corporate performance in Malaysia. International Journal of Commerce and Management, 20(2), 109-119. doi:10.1108/10569211011057245

35. Mukhtaruddin, M., Saftiana, Y., \& Dwikatama, P. A. (2018). Firm's Characteristics, Corporate Governance Quality, and Corporate Social Responsibility Disclosure. Sriwijaya International Journal of Dynamics and Business, 2(3), 193-212

36. Felmania, M. (2014). Good Corporate Governance Mechanism, Corporate Social Responsibility Disclosure on Firm Value: Empirical Study on Listed Company in Indonesia Stock Exchange. International Journal of Finance and Accounting Studies, 2(1), 1-10

37. Christina, S., \& Alexander, N. (2019, February). Corporate Governance, Corporate Social Responsibility Disclosure, and Earnings Management. Advances in Economics, Business and Management Research, 73, 62-65.

38. Fiona, J., Ritonga, K., \& Rusli, R. (2017). Pengaruh Corporate Social Responsibility Disclosure Terhadap Firm Value Dimoderasi Oleh Good Corporate Governance (Studi Pada Perusahaan Manufaktur Yang Terdaftar Di Bursa Efek Indonesia Tahun 2012-2014). Jurnal Online Mahasiswa Fakultas Ekonomi Universitas Riau, 4(1), 1570-1582

39. Giannarakis, G. (2014a). Corporate governance and financial characteristic effects on the extent of corporate social responsibility disclosure. Social Responsibility Journal, 10(4), 569-590. doi:10.1108/SRJ-02-2013-0008

40. Ilmi, M., Kustono, A. S., \& Sayekti, Y. (2017). Effect of good corporate governance, corporate social responsibility disclosure, and managerial ownership to the corporate value with financial performance as intervening variables: Case on Indonesia stock exchange. International Journal of Social Science and Business, 1(2), 75-88.

41. Munawaroh, M., Ghozali, I., Fuad, F., \& Faisal, F. (2018). The Trade-off Strategy between Financial and Environmental Performance: Assessment of Sustainable Value Added. International Journal of Energy Economics and Policy, 8(1), 5-11.

42. Listyaningsih, E., Dewi, R., \& Baiti, N. (2018). The Effect of Good Corporate Governance on Corporate Social Responsibility Disclosure on Jakarta Islamic Index. Indonesian Journal of Business and Entrepreneurship, 4(3), $273-281$.

43. Musta'ani, S. (2017). The Impact of Good Corporate Governance on the Corporate Social Responsibility Disclosure. Jurnal Keuangan dan Perbankan, 15(2), 223-238.

44. Yusran, I. A., Kristanti, F. T., \& Aminah, W. (2018). Pengaruh Indikator Good Corporate Governance Terhadap Corporate Social Responsibility Disclosure (Studi Pada Perusahaan Manufaktur Yang Terdaftar Di Bursa Efek Indonesia Periode 20112016). eProceedings of Management, 5(1), 621-627. 